\title{
PENGARUH PENJUALAN ONLINE \\ TERHADAP OMZET PENJUALAN BUTIK ZIETA \\ DESA SEWULAN KEC. DAGANGAN KAB. MADIUN
}

\author{
Dya Ayu Wulansari \\ Mahasiswa Prodi Pendidikan Ekonomi IKIP PGRI Madiun
}

\begin{abstract}
Abstrak:Tujuan penelitian ini adalah mengetahui penjualan lewat online pada butik busana muslim "Zieta" di Desa Sewulan Kecamatan Dagangan Kabupaten Madiun, untuk mengetahui omzet penjualan pada butik busana muslim "Zieta" di Desa Sewulan Kecamatan Dagangan Kabupaten Madiun. Penentuan sampel dalam penelitian ini menggunakan purposive sampling yaitu sampel yang diambil adalah laporan penjualan pada butik ZIETA sebelum dan sesudah melalukan penjualan lewat online selama 3 tahun per 6 bulan. Pengumpulan data menggunakan metode observasi, wawancara dan dokumentasi. Dalam menganalisis data menggunakan metode analisis statistik t test (uji t) dengan uji perhitungan manual data yang digunakan dalam analisis adalah data omzet penjualan sebelum dan sesudah adanya penjualan lewat online selama 3 tahun per 6 bulan. Hasil penelitian menunjukan bahwa penjualan online mempunyai beda pengaruh terhadap omzet penjualan pada butik busana muslim Zieta-Madiun. Untuk uji $t$ diperoleh nilai $t_{\text {hit }}$ adalah 19,67 sedangkan $t_{\text {tab }}$ adalah 1,943 . Hal ini berarti nilai $t_{\text {hitung }} \geq t_{\text {tabel }}(19,67 \geq 1,943)$. Dengan demikian $\mathrm{H}_{0}$ ditolak, artinya ada beda pengaruh penjualan lewat online terhadap omzet penjualan pada butik ZIETA Desa Sewulan Kecamatan Dagangan Kabupaten Madiun.
\end{abstract}

Kata Kunci: Penjualan Online, Omzet Penjualan

\section{PENDAHULUAN}

Globalisasi perekonomian merupakan suatu proses kegiatan ekonomi dan perdagangan, dimana negara-negara di seluruh dunia menjadi satu kekuatan pasar yang semakin terintegrasi dengan tanpa rintangan batas teritorial negara. Ketika globalisasi ekonomi terjadi, batas-batas suatu negara akan menjadi kabur dan keterkaitan antara ekonomi nasional dengan perekonomian internasional akan semakin erat. Globalisasi perekonomian akan membuka peluang pasar produk dari dalam negeri ke pasar internasional secara kompetitif, sebaliknya juga membuka peluang masuknya produk-produk global ke dalam pasar domestik.

Banyak perusahaan yang melakukan transformasi dari sistem tradisional menuju sistem modern yang sebagian besar melibatkan teknologi. Sejalan dengan cepatnya perkembangan bidang teknologi, perusahaan-perusahaan makin dipacu untuk menggunakan teknologi yang maju sebagai senjata untuk tetap survive dan memenangkan persaingan yang kian hari terasa ketat dan keras. Perusahaan yang mengabaikan teknologi dapat dipastikan akan tersingkir.

Teknologi internet sudah tidak asing lagi bagi beberapa pengusaha dan pelaku bisnis. Saat ini para pengusaha sudah banyak yang sudah memanfaatkan media internet sebagai sarana penginformasian produk yang dijual serta perbaikan pelayanan pelanggan, hal tersebut dilakukan semata - mata untuk meningkatkan omzet penjualan mereka, mengingat dunia maya tidak mengenal batasan ruang dan waktu. Chaniago (dalam 
Nissa dan Retno, 2013: 4-6) memberikan pendapat tentang omzet penjualan adalah keseluruhan jumlah pendapatan yang didapat dari hasil penjulan suatu barang/jasa dalam kurun waktu tertentu.

Salah satu konsep yang dinilai sebagai paradigma baru yang dikenal sebagai e-bisnis atau e-commerce akan terus semakin berkembang dan praktiknya berdampak besar dalam bisnis yang digunakan sebagai penyempurnaan direct marketing.

Adhi Prasetio (2012: 4) di kutip dari Wikipedia (2012) menyebutkan definisi E-commerce sebagai perdagangan eletronik atau e-dagang (bahasa inggris: electronic commerce, juga e-commerce) adalah penyebaran, pembelian, penjualan, pemasaran barang dan jasa melalui sistem elektronik seperti internet atau televisi, www atau jaringan komputer lainnya. E-dagang dapat melibatkan transfer dana elektronik, pertukaran data elektronik, sistem manajemen inventori otomatis, dan sistem pengumpulan data otomatis.

E-commerce merupakan bagian dari ebusiness, di mana cakupan e-business lebih luas, tidak hanya sekedar perniagaan tetapi mencakup juga pengkolaborasian mitra bisnis, pelayanan nasabah, lowongan pekerjaan dll. Selain teknologi jaringan www, e-dagang juga memerlukan teknologi basisdata atau pangkalan data (databases), esurat atau surat elektronik (e-mail), dan bentuk teknologi non komputer yang lain seperti halnya sistem pengiriman barang, dan alat pembayaran untuk e-commerce ini.

Dengan menggunakan Internet, dapat dibeli barang melalui dunia maya. Sistem penjualan on-line ini makin banyak dan makin banyak peminatnya. Sistem ini bisa juga disebut pasar virtual (virtual market). Bisnis secara online menjadi sebuah kesempatan yang besar. Dengan memanfaatkan kemajuan teknologi ini, dapat membantu usaha menengah ke bawah untuk bersaing. Sebuah langkah yang baik untuk mencoba melebarkan sayap di dunia bisnis.
Selain digunakan oleh perusahaanperusahaan besar maupun kecil, penjualan online juga digunakan oleh individu yang tidak terikat oleh instansi manapun untuk memulai suatu usaha ataupun menjadikannya sebagai lapangan bisnis. Walaupun dalam perkembangan bisnis internet milik sendiri dapat menjadi suatu hal yang sulit dihadapi, hal ini tidaklah lepas dari sistem website yang dimana berperan sebagai media pembantu adanya pasar cyber yaitu sebagai vendor penyedia layanan jasa transaksi secara online.

Butik ZIETA yang bergerak dibidang penjualan berbagai macam busana muslim untuk wanita dan anak-anak mulai berdiri tahun 2007. Produk butik ZIETA pada awalnya dipasarkan melalui mulut ke mulut. Seiring dengan perkembangan teknologi, penjualan tersebut mengalami penurunan dikarenakan kalah bersaing dengan butik lain yang sejenis. Dan sejak tahun 2009 pemilik butik berinisiatif memasarkan melalui internet atau penjualan lewat online karena dirasa oleh pemilik butik memiliki peluang besar dalam peningkatan omzet penjualan. Pada akhirnya, bersamaan dengan peningkatan kualitas informasi tersebut, juga diharapkan dapat memperbaiki kinerja butik menjadi lebih baik serta untuk menanggapi kebutuhan pelanggan akan informasi penjualan secara lebih luas yang berujung pada peningkatan omzet penjualan butik.

Butik ZIETA mengimplementasikan sistem informasi e-commerce dalam hal promosi penjualan produk mereka untuk meningkatkan jumlah profit perusahaan, dikarenakan sistem promosi dan penjualan barang yang dilakukan sekarang hanya menggunakan media promosi dari relasi kerja yang terbatas, dan walaupun sudah melakukan promosi menggunakan leaflet dan pamphlet tetap saja hasilnya kurang memuaskan karena hanya terbatas untuk lingkungan disekitarnya saja tidak mencakup semua.

Berdasarkan latar belakang diatas penulis tertarik mengangkat permasalahan dalam bentuk penelitian dengan judul "Pengaruh 
Penjualan Lewat Online Terhadap Omzet Penjualan Butik ZIETA Desa Sewulan Kec. Dagangan Kab. Madiun". Menurut Kalakota dan Whinston (dalam Siti Maryama, 2013: 73-74) mendefinisikan e-commerce dari beberapa perspektif berikut:

1) Perspektif komunikasi: e-commerce merupakan pengiriman informasi, produk/layanan, atau pembayaran melalui lini telepon, jaringan komputer atau sarana eletronik lainnya.

2) Perspektif proses bisnis: e-commerce merupakan aplikasi teknologi menuju otomisasi transaksi dan aliran kerja perusahaan.

3) Perspektif layanan: merupakan salah satu alat yang memenuhi keinginan perusahaan, konsumen dan manajemen dalam memangkas service cost ketika meningkatkan mutu barang dan kecepatan pelayanan.

4) Perspektif online: e-commerce berkaitan dengan kapasitas jual beli produk dan informasi di internet dan jasa online lainnya.

Menurut Abdul H. Barkatullah dan Teguh Prasetyo (2006: 18-23) e-Commerce dapat dibagi menjadi beberapa jenis yang memiliki karakteristik berbeda-beda yaitu:

1) Business to Business (B2B)

Business to Business e-Commerce memiliki karakteristik:

a) Trading partners yang sudah saling mengetahui dan antara mereka sudah terjalin hubungan yang berlangsung cukup lama. Pertukaran informasi berlangsung di antara mereka dan karena sudah sangat mengenal, maka pertukaran informasi dilakukan atas dasar kebutuhan dan kepercayaan.

b) Pertukaran data (data exchange) yang dilakukan secara berulang-ulang dan berkala format data yang telah disepakati. Jadi service yang digunakan antara kedua sistem tersebut sama dan menggunakan standar yang sama pula. c) Salah satu pelaku tidak harus menunggu partners mereka lainnya untuk mengirimkan data.

d) Model yang umum digunakan adalah peer-to-peer, dimana processing intelligence dapat didistribusikan di kedua pelaku bisnis.

2) Business to Consumer (B2C)

Business to Consumer e-Commerce memiliki karakteristik sebagai berikut:

a) Terbuka untuk umum, dimana informasi disebarkan ke umum.

b) Servis yang diberikan bersifat umum (generic) dengan mekanisme yang dapat digunakan oleh banyak orang. Sebagai contoh, karena sistem Web sudah umum di kalangan masyarakat maka sistem yang digunakan sistem web pula.

c) Service yang diberikan berdasarkan permohonan (on demand). Konsumen berinisiatif sedangkan produser harus siap merespon terhadap inisiatif konsumen tersebut.

d) Sering dilakukan pendekatan client/ server dimana konsumen di pihak client menggunakan sistem yang minimal (berbasis web) dan penyedia barang atau jasa (business prosedur) berada pada pihak server.

3) Consumen to Consumen (C2C)

Konsumen ke konsumen merupakan transaksi bisnis secara elektronik yang dilakukan antar konsumen untuk memenuhi suatu kebutuhan tertentu dan pada saat tertentu pula, segmentasi konsumen ke konsumen ini sifatnya lebih khusus karena transaksi dilakukan oleh konsumen ke konsumen yang memerlukan transaksi.

Internet telah dijadikan sebagai sarana tukar menukar informasi tentang produk baik mengenai harga, kualitas dan pelayanannya. Selain itu antar customer juga dapat membentuk komunitas pengguna/ penggemar produk tersebut. 
Chaniago (dalam Nissa dan Retno, 2013: 4-6) memberikan pendapat tentang omzet penjualan adalah keseluruhan jumlah pendapatan yang didapat dari hasil penjulan suatu barang/jasa dalam kurun waktu tertentu. Swastha (dalam Nissa dan Retno, 2013: 4-6)memberikan pengertian omzet penjualan adalah akumulasi dari kegiatan penjualan suatu produk barang barang dan jasa yang dihitung secara keseluruhan selama kurun waktu tertentu secara terus menerus atau dalam satu proses akuntansi.

Cara Meningkatkan Omzet Penjualan Tandjung (2010: 1-73), terdapat lima belas (15) jurus meningkatkan omzet penjualan, meliputi:

1. Belajar tentang: perusahaan, industri, pasar, dan pesaing Perusahaan, salesman harus mengenal perusahaan tempat mereka bergabung, juga produk yang hendak mereka jual.Kedua faktor tersebut merupakan senjata terpenting yang harus dimiliki para salesman.

2. Menetapkan Sasaran

Sasaran (goal) adalah suatu keadaan yang ingin dicapai oleh seseorang atau organisasi, bisa dalam jangka pendek, menengah maupun panjang.

3. Mengatur Agenda Kerja

Seorang salesman yang efektif juga perlu membuat perencanaan yang matang. Perencanaan sederhana seperti rute kunjungan dan daftar calon pelanggan yang hendak dikunjungi adalah kompas bagi salesman untuk melaksanakan aktifitas.

4. Memeriksa Perlengkapan

Setiap perusahaan perlu membekali perlengkapan tim penjualan sesuai kebutuhan dan jenis produk atau jasa yang dijual. Sering kali salesman kurang memperhatikan perlengkapan ini sebelum bertemu calon pembeli. Akibatnya, dapat mengganggu efektivitas presentasi.

5. Perhatikan Penampilan

Pakaian, Pastikan pakaian rapi saat ber- hadapan dengan pelanggan. Perhatikan juga kombinasi warna. Rambut, Perhatikan pertumbuhan rambut. Buatlah jadwal berkala untuk memotongnya. Jangan biarka rambut terlihat berantakan.

6. Optimis Bertemu Pelanggan

Optimis merupakan sikap selalu mempunyai harapan baik dalam segala hal serta kecenderungan untuk mengharapkan hasil yang menyenangkan.

7. MerawatKendaraan

Mengingat kendaraan sebagai alat transportasi yang penting bagi salesman, Maka perawatan rutin harus dilakukan agar kendaraan tidak mogok saat hendak berangkat kerja atau ditengah perjalanan.

8. Jangan Lupa Menutup Transaksi

Bagian akhir dari serangkaian kegiataan yang harus dilakukan oleh salesman. Closing bisa dikatakan sukses, bila calon pembeli melakukan transaksi pembelian.

9. Mencari Prospek Baru

Para salesman sering terlalu asik dengan pembeli yang sudah ada. Akibatnya, mereka jarang mencari calon pembeli baru padahal mendapatkan pembeli baru dapat meningkatkan omzet penjualan.

10. Melakukan Evaluasi

Sebuah proses penilaian atas kinerja atau kegiatan yang telah dilakukan. Evaluasi sangat berguna karena dapat menghemat biaya atau sumber daya yang diperlukan untuk kegiataan berikutnya.

11. Olahraga Bersama Rekan

Salesman perlu memperhatikan kesehatannya, baik fisik dan mental agar mampu bekerja secara optimal.

12. Memahami Pelanggan

Masing-masing pelanggan memiliki kebutuhan dasar yang beragam. Motif pembelian yang mereka lakukan juga berbeda. Hal ini bergantung pada faktor sosial dan ekonomi setiap pelanggan. Salesman, dalam hal ini perlu memperhatikan dan memahami kedua hal tersebut jika ingin menjual. 


\section{Mengikuti Pelatihan Keterampilan} Menjual

Mengikuti pelatihan atau seminar dapat meningkatkan kinerja penjualan, maka tidak ada salahnya menyisihkan sebagian pendapatan untuk bisa mengikuti kegiatan positif ini.

14. Mencari Prospek Kakap

Sekali kita bisa menangkap pelanggan dengan karegori kakap ini, biasanya bisa dipastikan perolehan target penjualan di perusahaan akan aman. Tenaga dan waktu untuk kujunganpun tidak perlu tersebar kebanyak pelanggan.

\section{Melakukan Konsultasi}

Konsultasi bisa dilakukan antar rekan kerja dengan kualitas yang setara dengan kita, maupun dengan seorang yang memiliki kapasitas lebih baik dari diri kita.

Dari definisi di atas dapat disimpulkan bahwa omzet penjualan adalah keseluruhan jumlah penjualan barang/jasa dalam kurun waktu tertentu, yang dihitung berdasarkan jumlah uang yang diperoleh. Seorang pengelola usaha dituntut untuk selalu meningkatkan omset penjualan dari hari ke hari, dari minggu ke minggu, dari bulan ke bulan dan dari tahun ke tahun. Hal ini diperlukan kemampuan dalam mengatur modal terutama modal kerja agar kegiatan operasional perusahaan dapat terjamin kelangsungannya.

\section{Metode Penelitian}

Tempat untuk penelitian yaitu pada butik pakaian muslim "ZIETA", Desa Sewulan Kecamatan Dagangan Kabupaten Madiun. Tempat tersebut letaknya sangat strategis karena berada di dekat pasar yang letaknya sering dikunjungi dan dilewati masyarakat. Desain penelitian yang digunakan adalah penelitian eksperimen. Penelitian eksperimen didefinisikan sebagai metode penelitian yang digunakan untuk mencari pengaruh perlakuan tertentu terhadap yang lain dalam kondisi yang terkendalikan
(Sugiyono, 2010: 107). Penelitian eksperimen yang digunakan adalah Posttest-Only Control Design, peneliti menggunakan desain ini karena dalam desain ini, peneliti dapat mengontrol semua variabel luar yang mempengaruhi jalannya eksperimen.

Dalam penellitian ini teknik pengumpulan data dilakukan melalui observasi, wawancara, dan dokumentasi. Metode observasi digunakan untuk mengetahui tentang pengaruh penjualan lewat online terhadap omzet penjualan butik ZIETA. Metode wawancara digunakan untuk mengetahui tentang pengaruh penjualan lewat online terhadap omzet penjualan butik ZIETA. Dan metode dokumentasi digunakan untuk mengetahui kegiatan produksi, kegiatan penjualan lewat online, jenis busana yang diproduksi, dan omzet penjualan.

\section{Populasi dan Sampel}

Populasi merupakan objek yang akan diteliti, (Sugiyono, 2010: 117) menyatakan Populasi adalah wilayah generalisasi yang terdiri atas obyek subyek yang mempunyai kualitas dan karakteristik tertentu yang ditetapkan oleh peneliti untuk dipeleajari dan kemudian ditarik kesimpulannya. Populasi dalam penelitian ini adalah seluruh laporan penjualan yang ada pada butik ZIETA mulai tahun 2007-2012. Sampel merupakan sebagaian dari populasi (Sugiyono, 2010: 118) mengatakan sampel adalah bagian dari jumlah dan karakteristik yang dimilliki oleh populasi tersebut. Yang menjadi sampel adalah laporan penjualan pada butik ZIETA sebelum dan sesudah melalukan penjualan lewat online selama 3 tahun per 6 bulan, yaitu sebelum melakukan penjualan lewat online mulai bulan Maret dan September 2007, bulan Maret dan September 2008 dan bulan Maret dan September 2009. Sedangkan sesudah melakukan penjualan lewat online mulai bulan Maret dan September 2010, bulan Maret dan September 2011 dan bulan Maret dan September 2012. 


\section{Variabel Penelitian}

Variabel bebas adalah variabel yang mempengaruhi atau yang menjadi sebab perubahannya atau timbulnya variabel dependen (Sugiyono, 2007: 4). Dalam penlelitian ini variabel bebas $\mathrm{X}$ ada dua yaitu variabel (X1) yaitu sebelum melalukan penjualan lewat online dan variabel (X2) yaitu sesudah melalukan penjualan lewat online.

Variabel independent adalah variabel yang dipengaruhi atau yang menjadi akibat, karena adanya variabel bebas (Sugiyono, 2007: 4). Dalam penelitian ini yang menjadi variabel independent adalah variabel (Y) omzet penjualan.

\section{Hasil Penelitian}

Penjualan lewat online sangat diperlukan untuk dapat meningkatkan omzet penjualan. Sebelum adanya penjualan lewat online omzet penjualan yang dicapai kurang begitu memuaskan, tetapi dengan adanya penjualan lewat online melalui berbagai jejaring social seperti facebook, twitter, BBM, dan blog dapat memperluas jaringan penjualan butik untuk memasarkan produk butik sehingga konsumen pun tertarik untuk membeli, sehingga dengan demikian omzet penjualan dapat mengalami peningkatan.

Untuk 3 tahun penjualan sebelum adanya penjualan lewat online presentase omzet penjualan masih dibawah rata-rata kenaikan hanya terjadi pada bulan juni dilain bulan itu omzet penjualan tidak mengalami kenaikan yang berarti. Dapat dideskripsikan bahwa sebelum pengembangan produk dari $\mathrm{N}$ sebanyak 6 , yang berada diatas nilai rata-rata sebanyak $3 \mathrm{~N}$ atau 50\%. Sedangkan yang berada dibawah nilai rata-rata sebanyak $3 \mathrm{~N}$ atau 50\%. Berdasarkan hasil analisis Deskriptif data sebagai berikut: (a) jumlah skor total sebesar 424; (b) rata-rata hitung (mean) sebesar 70.66; (c) median sebesar 74.50; (d) modus sebesar 80; (e) standar deviasi sebesar 65.186; (f) minimum sebesar 152; (g) maximum sebesar 341.
Penjualan lewat online dalam suatu perusahaan dalam hal ini adalah butik pakaian muslim sangat penting untuk dilakukan. Kegiatan penjualan lewat online memiliki peran penting dalam menunjang pengembangan butik. Dengan adanya penjualan lewat online akan menarik minat konsumen untuk membeli barang tersebut, sehingga dengan adanya peningkatan pembelian akan dapat menambah penjualan yang dapat memberikan laba atau keuntungan untuk butik yang bersangkutan.

Penjualan lewat online yang dilakukan oleh butik ZIETA Desa Sewulan Kecamatan Dagangan Kabupaten Madiun merupakan salah satu upaya untuk meningkatkan omzet penjualan.

Untuk 3 tahun penjualan sesudah adanya penjualan lewat online presentase omzet penjualan mengalami kenaikan, walaupun sempat mengalami penurunan pada bulan juni 2010 dan desember 2012 tapi di bulan-bulan lain omzet penjualan mengalami kenaikan. Dapat dideskripsikan bahwa variabel sebelum pengembangan produk dari $\mathrm{N}$ sebanyak 6 , yang berada diatas nilai ratarata sebanyak $4 \mathrm{~N}$ atau $66 \%$. Sedangkan yang berada dibawah nilai rata-rata sebanyak $2 \mathrm{~N}$ atau 34\%. Berdasarkan hasil analisis Deskriptif data sebagai berikut: (a) jumlah skor total sebesar 507; (b) rata-rata hitung (mean) sebesar 84.50; (c) median sebesar 87.32; (d) modus sebesar 95; (e) standar deviasi sebesar 69.351; (f) nilai minimum sebesar 288; (g) nilai maximum sebesar 403.

\section{Hasil Uji t}

Untuk uji hipotesis beda pengaruh pepenjualan lewat online terhadap omzet penjualan dapat dibuat tabel kerja untuk menghitung uji t sebagai berikut:

Untuk uji $t$ diperoleh nilai $t_{\text {hit }}$ adalah 19,67 sedangkan $t_{\text {tab }}$ adalah 1, 943. Hal ini berarti nilai $t_{\text {hitung }} \geq t_{\text {tabel }}(19,67 \geq 1,943)$. Dengan demikian $\mathrm{H}_{0}$ ditolak, artinya ada beda pengaruh penjualan lewat online terhadap omzet penjualan pada butik ZIETA Desa 
Sewulan Kecamatan Dagangan Kabupaten Madiun.

\section{PEMBAHASAN HASILANALISIS Pembahasan Ujit}

Hasil dari uji $t$ dapat diperoleh nilai $t_{\text {hit }}$ adalah 19,67 sedangkan $t_{\text {tab }}$ adalah 1,943. Hal ini berarti bahwa nilai $t_{\text {hitung }} \geq t_{\text {tabel }}(19,67 \geq$ 1,943). Sesuai hipotesis yang diajukan dapat diperoleh simpulan bahwa ada beda pengaruh penjualan lewat online terhadap omzet penjualan pada butik ZIETA Desa Sewulan Kecamatan Dagangan Kabupaten Madiun. berarti $\mathrm{H}_{0}$ ditolak.

\section{Pembahasan Ujit}

Hasil penelitian yang sudah dilakukan menunjukkan bahwa ada beda pengaruh penjualan lewat online terhadap omzet penjualan. Hal ini menunjukkan bahwa penjualan lewat online sangat diperlukan untuk dapat meningkatkan omzet penjualan. Selanjutnya adalah pembahasan untuk ujit:

Untuk uji t diperoleh nilai $t_{\text {hit }}$ adalah 19,67 sedangkan $t_{\text {tab }}$ adalah 1, 943. Hal ini berarti nilai $t_{\text {hitung }} \geq t_{\text {tabel }}(19,67 \geq 1,943)$. Dengan demikian $\mathrm{H}_{0}$ ditolak, artinya ada beda pengaruh penjualan lewat online terhadap omzet penjualan pada butik ZIETA Desa Sewulan Kecamatan Dagangan Kabupaten Madiun.

Dari hasil penelitian menunjukkan bahwa ada beda pengaruh penjualan lewat online terhadap omzet penjualan .

Hal ini disebabkan adanya penjualan lewat online melalui berbagai macam jenis jejaring social seperti facebook, twitter, BBM, dan Blog dengan cara penyebaran penjualan busana muslim yang semakin luas, sehingga konsumen yang dimana pun lokasi/tempatnya dapat dijangkau melalui penjualan online untuk membeli produk ini. Oleh karena itu penjualan lewat online sangat diperlukan untuk dapat meningkatkan omzet penjualan.
Sesuai dengan pendapat Menurut Gary Coulter dan John Buddemeir (E-commerce Outline) : e-commerce berhubungan dengan penjualan, periklanan, pemesanan produk, yang semuanya dikerjakan melalui internet. System penjualan modern melalui onlinel internet akan membentuk masa depan perusahaan, memperbaiki ataupun menggantikan system penjualan lama/tradisional yang dianggap kurang mampu menjangkau pasar penjualan yang lebih luas, dengan penjualan lewat online diharapkan mampu memelihara dan meningkatkan omzet penjualan".

\section{PENUTUP}

\section{Kesimpulan}

Berdasarkan hasil analisis data dan pembahasan pada penelitian tentang pengaruh penjualan lewat online terhadap omzet penjualan butik ZIETA Desa Sewulan Kec. Dagangan Kab. Madiun dan hasil analisis serta pembahasan maka penulis dapat menyimpulkan hal-hal sebagai berikut: Penjualan lewat online pada butik ZIETA Desa Sewulan Kec. Dagangan Kab. Madiun berhasil. Hal ini dapat dilihat dari banyaknya media sosial yang digunakan sebagai fasilitas untuk berjualan melalui online seperti pada BBM (BlackBerry Messenger), Facebook, Twitter, dan Blog. Dengan pemanfaatan media sosial tersebut penjualan butik ZIETA dapat menjangkau wilayah yang luas tidak hanya diwilayah Madiun tapi seluruh wilayah Indonesia dapat dijangkau. Hal ini mampu menekan biaya pemasaran. Berdasarkan hasil wawancara dengan saudara Furqan ditempat butik ZIETA Desa Sewulan Kec. Dagangan Kab. Madiun, Tanggal 24 April 2013 pada jam 10.00 WIB mengatakan bahwa penjualan lewat online yang telah dilakukan berdampak positif terhadap penjualan, dengan sistem penjualan lewat online mempermudah calon pembeli yang tidak bisa menjangkau wilayah penjualan butik ZIETA yang berada di Madiun. Dilain pihak hasil wawancara dari salah satu karyawan yang bernama Titin 
mengatakan bahwa penjualan lewat online sangat membantu dalam penjualan, karena konsumen merasa lebih praktis dan menghemat waktu dan biaya dalam membeli produk dari butik ZIETA. Dibutik ini yang paling disukai pelanggan adalah busana kaftan remaja dan baju koko anak-anak. Dalam berproduksi selama ini kami selalu memberikan produk yang terbaik untuk masyarakat, salah satunya untuk menarik pelanggan adalah dengan memberikan pelayanan penjualan lewat online. Untuk 3 tahun penjualan sebelum adanya penjualan lewat online rata-rata penjualan sebesar $25,44 \%$. Sedangkan untuk 3 tahun sesudah penjualan lewat online rata-rata mencapai $30,42 \%$. Omzet penjualan pada butik ZIETA Desa Sewulan Kec. Dagangan Kab. Madiun baik. Hal tersebut terbukti dari setiap minggunya penjualan mengalami kenaikan. Hal ini dapat dilihat dari hasil analisis data omzet penjualan sebelum dan sesudah adanya penjualan lewat online. Data omzet penjualan sebelum penjualan lewat online dari $\mathrm{N}$ sebanyak 6 , yang berada diatas nilai rata-rata sebanyak 3 minggu atau 50\%. Sedangkan yang berada dibawah nilai rata-rata sebanyak 3 minggu atau 50\%. Berdasarkan hasil analisis statistik deskriptif dengan jumlah (N) sebanyak 6 diperoleh data sebagai berikut: (a) jumlah skor total sebesar 424; (b) rata-rata hitung (mean) sebesar 70.66; (c) median sebesar 74.50; (d) modus sebesar 80; (e) standar deviasi sebesar 65.186; (f) minimum sebesar 152; (g) maximum sebesar 341.Sedangkan omzet penjualan sesudah penjualan lewat online dari $\mathrm{N}$ sebanyak 6, yang berada diatas nilai rata-rata sebanyak 4 minggu atau $66 \%$. Sedangkan yang berada dibawah nilai rata-rata sebanyak 2 minggu atau 34\%. Berdasarkan hasil analisis statistik deskriptif dengan jumlah (N) sebanyak 13 diperoleh data sebagai berikut: (a) jumlah skor total sebesar 507; (b) rata-rata hitung (mean) sebesar 84.50; (c) median sebesar 87.32; (d) modus sebesar 95; (e) standar deviasi sebesar 69.351; (f) nilai minimum sebesar 288; (g) nilai maximum sebesar 403. Penjualan lewat online mempunyai pengaruh terhadap omzet penjualan pada butik ZIETA Desa Sewulan Kec. Dagangan Kab. Madiun. Hal tersebut terbukti dari hasil analisis uji t yaitu diperoleh nilai thit adalah 19,67 sedangkan $\mathrm{t}_{\text {tab }}$ adalah 1,943. Hal ini berarti bahwa nilai $t_{\text {hitung }} \geq t_{\text {tabel }}(19,67 \geq$ 1,943). Sesuai hipotesis yang diajukan dapat diperoleh simpulan bahwa ada beda pengaruh penjualan lewat online terhadap omzet penjualan pada butik ZIETA Desa Sewulan Kecamatan Dagangan Kabupaten Madiun.

\section{Saran}

1. Bagi karyawan

Penjualan lewat online mempunyai pengaruh terhadap omzet penjualan, oleh karena itu karyawan dan pemilik butik busana muslim tersebut harus bersungguh-sungguh dalam melakukan penjualan lewat online. Caranya dengan lebih memaksimalkan lagi penjualan lewat online yang telah dilakukan, diharapkan selalu mengupload fotofoto/model busana terbaru di sosial media sehingga butik maupun pelanggan dapat selalu update perkembangan produk yang dijual oleh butik ZIETA. Selain itu untuk melakukan penjualan lewat online diperlukan keahlian dalam mengelolanya, sehingga pemimpin bisa memberikan pelatihan tentang bagaimana melakukan penjualan lewat online yang baik, agar karyawan lebih mengerti bagaimana tahap-tahap yang harus dilakukan saat melakukan penjualan lewat online. Penjualan lewat online merupakan salah satu cara untuk meningkatkan omzet penjualan dan menambah penghasilan untuk butik busana muslim tersebut. Dengan adanya penjualan lewat online, diharapkan konsumen tertarik dengan busana muslim yang telah diproduksi, sehingga tetap membeli barang tersebut. 
2. Bagiperusahaan

Penjualan lewat online hendaknya tetap dilaksanakan secara berkesinambungan untuk setiap produk yang dihasilkan, supaya dapat mempermudah pelanggan dalam membeli produk, menekan biaya produksi dan dapat memperluas wilayah penjualan butik ZIETA. Hal tersebut dilakukan agar keuntungan yang diperoleh butik tersebut mengalami peningkatan.

3. Bagi peneliti mendatang

Bagi peneliti yang selanjutnya, sebaiknya untuk melakukan penelitian yang akan datang dapat menggunakan variabel lain yang lebih bervariasi lagi misalnya penjualan lewat online berpengaruh pada biaya produksi atau minat konsumen, karena masih banyak faktorfaktor yang dapat mempengaruhi omzet penjualan selain penjualan lewat online.

\section{DAFTAR PUSTAKA}

Abdul H. Barkatullah. 2006. Bisnis ECommerce: Studi Sistem Keamanan Hukum Di Indonesia. Yogyakarta: Pustaka Pelajar.

Adhi Prasetio. 2012. Jualan Online. Jakarta: Mediakita.

Basu Swastha. 2002. Azas Azas Marketing. Yogyakarta: Liberty.

Basu Swastha dan Ibnu Sukotjo. 2002. Pengantar Bisnis Modern: Pengantar Ekonomi Perusahaan Modern .Yogyakarta: Liberty.

Basu Swastha dan Irawan. 2008. Manajemen Pemasaran Modern. Yogyakarta: Liberty.

Blocher Chen Cokins Lin. 2007. Cost Management: Management Biaya. Jakarta: Salemba Empat.
Departemen Pendidikan Nasional. 2008. Kamus Besar Bahasa Indonesia Pusat Bahasa. Jakarta: Gramedia.

Duwi Priyatno. 2010. Teknik Mudah Dan Cepat Melakukan Analisis Data Penelitian SPSS. Yogyakarta: Gava Media.

Freddy Rangkuti. 2009. Strategi Promosi yang Kreatif. Jakarta: Gramedia.

Harimurti Subanar. 2001. Manajemen Usaha Kecil. Yogyakarta: BPFE.

Jenu W. Tandjung dan Teguh Prayoga. 2012. 31 Hari Sukses Meningkatkan Omzet Penjualan. Jakarta: Kompas Gramedia.

Jubilee Enterprise. 2013. Toko Online Modern. Jakarta: Kompas Gramedia.

Kotler Philip. 2002. Manajemen Pemasaran. Jakarta: Prenhallindo.

Lili M. Sadeli dan Maman Ukas. 2000. Pengantar Ilmu Menjual. Jakarta: Bumi Aksara.

Nasution. 2004. Metode Research. Jakarta: Bumi Aksara.

Nissa Nurfitria dan Retno Hidayati. Analisis Perbedaan omzet Penjualan Berdasarkan Jenis Hajatan Dan Waktu (Studi Pada Catering Sonokembang Semarang). Jurnal Liquidity, Vol. 1 (nissanurfitria@yahoo.com, diakses 02 Oktober 2013)

Raymond McLeod dan George Schell. 2004. Sistem Informasi Manajemen edisi kedelapan. Jakarta: Prenhall.

Raymond McLeod dan George Schell. 2007. Sistem Informasi Manajemen edisi 10. Jakarta: Prenhall.

Siti Maryama. 2013. Penerapan E-Commerce Dalam Meningkatkan Daya Saing Usaha. Jurnal Liquidity, Vol. 2, No. 1 (sitimaryama@yahoo.com, diakses 02 Oktober 2013) 
Sugiyono. 2010. Metode Penelitian Pendidikan: Pendekatan Kuantitatif, Kualitatif, dan R\&D. Bandung: Alfabeta.

Sugiyono. 2007. Statistika untuk Penelitian. Bandung: Alfabeta.
Terence A. Shimp. 2000. Periklanan Promosi Jilid I. Jakarta. Erlangga Jakarta.

Terence A. Shimp. 2001. Periklanan Promosi Jilid II. Jakarta. Erlangga.

Ulber Silalahi. 2010. Metode Penelitian Sosial. bandung: PT. Refika Aditama. 